\title{
María Guadalupe Suárez. Fotógrafa de vistas
}

\author{
LaUra Castañeda García \\ Posgrado en Artes y Diseño \\ Facultad de Artes y Diseño \\ Universidad Nacional Autónoma de México \\ laura.castaneda.g@gmail.com
}

\begin{abstract}
Resumen
Se describe un conjunto de fotografías realizadas por María Guadalupe Suárez, en el marco de recuperar a este personaje considerado la primera mujer en instalar un estudio fotográfico en el Distrito Federal en 1881. Estas fotografías fueron parte del Álbum fotográfico de México, editado por esta fotógrafa y conforman un caso singular de registros llamados "de exteriores" en México. Estos registros fotográficos se realizaron entre septiembre del año 1882 y enero de 1883, según se indica en anuarios de la época y la hoja impresa de referencia que acompaña a cuatro de las imágenes.
\end{abstract}

Palabras clave: fotografía; fotógrafa; María Guadalupe Suárez; estudio fotográfico; vistas.

\section{María Guadalupe Suárez. View Photographer}

\begin{abstract}
This article describes a set of photographs by María Guadalupe Suárez as part of the attempts to rediscover this figure, regarded as the first woman to set up a photographic studio in Mexico City in 1881. These photographs were part of the Álbum fotográfico de México, edited by this photographer, and comprise an unusual case of records "of exteriors" in Mexico. These photographic records were produced between September 1882 and January 1883, according to the directories of the time and the printed reference sheet accompanying four of the images.
\end{abstract}

Key words: photography; photographer; María Guadalupe Suárez; photographic studio; views.

Fecha de recepción: Fecha de aceptación:

21 de mayo de 20139 de junio de 2014 


\title{
María Guadalupe Suárez. Fotógrafa de vistas
}

\author{
Laura Castañeda García
}

$\mathrm{E}$ n una investigación en curso que tiene como tema la fotografía del Distrito Federal de los años 1880 a 1885 , varios estudiosos de la fotografía ${ }^{1}$ nos hemos dado a la tarea de analizar en particular el tipo de imágenes llamadas "vistas". Aunque en el seminario interdisciplinario nos encontramos en proceso de investigar y explicar el término con mayor amplitud, en estas líneas podemos decir que el concepto "vistas" fue utilizado desde la misma invención de la fotografía y perduró a lo largo del siglo XIX. ${ }^{2}$ Como veremos más adelante para el caso de María Guadalupe Suárez, así como de fotógrafos o firmas fotográficas mexicanas poco conocidas como la familia Munguía,

\footnotetext{
${ }^{1}$ Miembros del seminario: Fernando Aguayo (coordinador), Berenice Valencia, Daniela Carreón, Lilia Martínez, Laura Castañeda.

${ }^{2}$ En una carta escrita en 1827 , Joseph Nicéphore Niépce le escribe a Daguerre: "Este resultado ni siquiera es reciente, corresponde a la primavera pasada; desde entonces me he visto apartado de mis investigaciones por otras ocupaciones. Hoy voy a retomarlas, ahora que el campo está en el momento más espectacular, y me voy a dedicar exclusivamente a la copia de puntos de vista del natural." Con esta expresión, Niepce hace la diferencia entre sus novedosos registros realizados a partir de un motivo natural, de otros ensayos en los que simplemente se reproducían imágenes contenidas en grabados.
}

Lorenzo Becerril y Luciano Gallardo, al igual que famosos extranjeros como Alfred Briquet, Gove \& North y William Henry Jackson, ofrecieron a la venta grupos de fotografías a las que denominaron Vistas mexicanas.

Jean-François Chevrier (2007, pp. 4149) señala la relación que une a la representación del espacio urbano, arquitectónico o natural, con las especulaciones sobre la visión óptica y la perspectiva, lo que llevó a muchos pintores del siglo XVIII a utilizar la cámara oscura, antecesor de la cámara fotográfica. Esta voluntad de representación del espacio coexistió con la búsqueda de lo pintoresco y lo sublime en el arte del paisaje en el siglo XIX. ${ }^{3}$ Por su parte, las personas que ejercieron el oficio de fotógrafo en los primeros tiempos estaban inmersos en una cultura rica y múltiple en lo que respecta a la creación de

\footnotetext{
${ }^{3}$ Esta preocupación por la representación correcta del espacio y la perspectiva, como punto de partida de la creación de la pintura de paisaje, se pude ver claramente en la obra del pintor italiano Eugenio Landesio, quien formó a muchos artistas de la famosa Escuela Mexicana. Landesio (1867), en su libro La pintura general o de paisaje y de perspectiva, en la Academia de San Carlos, divide el paisaje en localidades y episodios; a las primeras sintetiza los diferentes tipos de lugares, y en el segundo la historia y las escenas.
} 
imágenes, entre esos saberes y habilidades en la creación, se encontraba precisamente el paisaje, género pictórico bien establecido por las academias de la época.

De hecho, Chevrier (2007) y Rosalin Krauss (2002) señalan que hubo entre los primeros fotógrafos quienes se consideraban a sí mismos artistas, querían hacer fotografía de paisaje y buscaban exponer sus obras en salas adecuadas a la representación de su arte. En cambio, otros, sin que se piense en una separación tajante, insistían en la creación de imágenes en las que, desde un "punto de vista específico", se lograra la representación singular del espacio. Esta actitud es la que los lleva a referir a sus imágenes como "vistas topográficas", o, simplemente, vistas. ${ }^{4}$ En este tipo de fotografías, más que una interpretación subjetiva, se tienen imágenes en las que se representa un espacio singular al encuadrar un referente con una cámara, eligiendo la posición y ángulos de toma, desde un punto de vista previamente escogido.

Por ello, "vista" fue el término constantemente empleado en las publicaciones fotográficas en el mundo, así como la

\footnotetext{
${ }^{4}$ Aunque ambos autores señalan herencias, tradiciones y hasta formación de los fotógrafos, es importante señalar que existen diferencias, incluso al comentar un mismo caso, pues al referirse a las misiones topográficas estadunidenses en el siglo XIX, Chevrier (2007) pone énfasis en que los fotógrafos "participaban de una estrecha convergencia de intereses científicos y prácticos, pero estuvieron también muy condicionadas por consideraciones estéticas y teológicas" (p. 51). En cambio, en su conocido artículo, Krauss (2002) utiliza el ejemplo de una de esas misiones para insistir en lo específico de los "espacios discursivos de la fotografía”. Concepto que nos parece pertinente recuperar para el tema de las "vistas fotográficas", motivo de nuestra investigación.
}

denominación fundamental que los fotógrafos dieron a sus obras "en lugar del término paisaje como categoría descriptiva" (Krauss, 2002, pp. 153-154).

En nuestra búsqueda, los miembros del seminario La Fotografía del Distrito Federal, 1880-1885 hemos encontrado obras de importantes productores que publicaron grupos de estas imágenes, y comenzamos el estudio de similitudes y diferencias en el trabajo de los fotógrafos que las realizaron. En esta tarea me sorprendió el importante hallazgo de diez fotografías realizadas por María Guadalupe Suárez, que aunque este personaje ha sido mencionada en publicaciones recientes, ${ }^{5}$ sólo se ha hecho referencia a su trabajo a partir de documentos hemerográficos de la época. En cambio, en este texto nuestra principal fuente de investigación fueron las fotografías de María Guadalupe Suárez que se localizaron como parte de la investigación de la década de 1880. Este marco sirve, además, para señalar que sus temas y encuadres fotográficos fueron diferentes a los de otros fotógrafos contemporáneos como Alfred Briquet, William Henry Jackson, la firma Gove \& North, o el mexicano Lorenzo Becerril.

María Guadalupe Suárez es sin duda una de las primeras fotógrafas mexicanas, pese a que en sus inicios este oficio fue considerado como uno de varones, posi-

${ }^{5}$ Abida Ventura en su artículo "El misterio de las fotógrafas pioneras", publicado en El Universal el 28 de mayo de 2011, escribe sobre la entrevista realizada a José Antonio Rodríguez en torno a la curaduría de la exposición Otras miradas. Fotógrafas en México, 1872-1960: "Una de ellas es María Guadalupe Suárez, de quien, según el crítico, únicamente se conoce una fotografía”. Véase también Rodríguez (2012). 
blemente por lo complicado y peligroso de los procesos fotográficos y por el gran peso de los equipos de la época y las placas de cristal mucho más pesadas y delicadas que los negativos actuales. Sin embargo, como podemos observar, las mujeres también se formaron en el oficio. Si bien las presentes líneas son un avance de investigación -ya que se seguirá trabajando en el tema- nos parece pertinente compartir este importante descubrimiento.

María Guadalupe Suárez fue la primera mujer en instalar un estudio fotográfico en el Distrito Federal: ${ }^{6}$ en 1881 montó su estudio-taller en la calle de Chiconautla número 3, en la actual República de Colombia en la zona centro de la ciudad de México. Ella misma construyó los aparatos de fotografía indispensables ${ }^{7}$ y hasta el cuarto de madera en donde revelaba los retratos en ese estudio, "en donde realizaba retratos magníficos al precio de doce y medio centavos cada uno". ${ }^{8}$ Es también en este lugar donde realizó el Álbum fotográfico de México, que al parecer tuvo diferentes tipos de ediciones; las imágenes que encontramos pertenecen a una edición económica, como se anota en el soporte de las fotografías.

Los avisos publicados en un anuario de 1883 advierten que "se hace toda clase de trabajos concernientes al ramo. Precios equitativos, se garantiza el esmero y la exactitud en el trabajo" (Mata, 1883, sec-

\footnotetext{
${ }^{6}$ La Srita. Guadalupe Suárez. La Libertad, 23 de enero de 1881, año IV, núm. 12, Distrito Federal, México, p. 3.

${ }^{7} \mathrm{La}$ nota hemerográfica no hace referencia a qué aparatos construyó.

${ }^{8}$ La educación de las mujeres. La Libertad, 21 de enero de 1881, año IV, núm. 14, Distrito Federal, México, p. 2.
}

ción de avisos) y referente al Álbum fotográfico de México mencionan que se trata de una colección de vistas, monumentos, tipos, antigüedades, etc. Al parecer, se publicaba una entrega a la semana, misma que se ofrecía en 18.75 pesos en la capital y en 25 pesos en los estados; de igual manera, las fotografías sueltas se vendían en 50 centavos. Para adquirir las imágenes, las suscripciones se hacían en la casa de la fotógrafa, que se encontraba en la calle de Puente de Correo Mayor número 7 1/2 (actualmente Correo Mayor entre Corregidora y Venustiano Carranza). Desafortunadamente no pudimos ubicar el edificio en cuestión debido a que la numeración ha cambiado y a que los comercios tapan con sus marquesinas buena parte de las entradas de los edificios.

Las imágenes localizadas son del Distrito Federal y las fotografías están resguardadas en la Fototeca Nacional y en la Coordinación Nacional de Monumentos Históricos. La primera conserva positivos en albúmina y la segunda reprografías en placas de nitrato de plata en formato $5 \times 7$ pulgadas. Una característica sobresaliente de estos interesantes objetos es que seis de los positivos conservados en la Fototeca Nacional conservaron una hoja impresa. Estas entre hojas, que seguramente acompañaban todos los registros fotográficos del citado Álbum fotográfico de México, contienen diversos datos que citaremos más adelante, en particular ahí se indica que las fotografías se realizaron entre septiembre de 1882 y enero de 1883 .

Estudiando todas las vistas se deduce que fueron fotografiadas en placas negativas de cristal en técnica al colodión húmedo. Esta técnica representaba todo un reto para cualquier fotógrafo, por lo que María Guadalupe Suárez debía llevar y 
preparar su grande y pesada cámara de madera sobre un tripié fuerte y estable, posteriormente encuadraba y realizaba ajustes al fuelle de la cámara, enfocaba y preparaba las placas en un laboratorio portátil para lo que se utilizaba comúnmente una especie de tienda de campaña o un carromato para evitar la exposición a la luz y añadirle movilidad al laboratorio (Sougez y Pérez, 2003, p. 116).

Casi en total oscuridad debía preparar la solución de nitrocelulosa (colodión) con alcohol y éter, procedía a recubrir la placa de cristal con la emulsión, la aplicaba de manera horizontal y poco a poco la iba inclinando para que la solución espesa se esparciera uniformemente sin manchar el reverso del cristal, enseguida sumergía la placa en un baño de yoduro de plata, la escurría y colocaba en un chasís de madera.

Posteriormente, ya fuera del laboratorio, colocaba el chasís en la cámara, lo abría quitando la cortina de seguridad, realizaba la toma con un tiempo de exposición de entre dos y 20 segundos, según la iluminación con que contara la escena. Debía regresar al cuarto oscuro en donde revelaba con rapidez para mantener húmedo el colodión durante el proceso, fijaba, lavaba, secaba la placa y le colocaba un barniz para proteger la fina capa negativa (Sougez, 1999, pp. 127-131).

Este procedimiento debía repetirlo en cada toma fotográfica, por lo que requería de mucha experiencia y aun así era difícil tener una técnica pulida. Además la emulsión que preparaba debía ser de una sensibilidad baja que le permitiera exposiciones largas, esto lo podemos corroborar en fotografías como la de la iglesia de Santiago Tlatelolco, que muestra a una persona en movimiento barrido que se captura con este tipo de exposición, tam- bién debía procurar que la emulsión tuviera alta latitud que le permitiera obtener una amplia gama tonal y detalle tanto en las luces como en las sombras.

Las cámaras profesionales de la época eran de fuelle, por lo que se vislumbra que utilizó una de ellas debido a que no se conoce la existencia de la cámara fotográfica ni de algún negativo, y por el tamaño de los positivos que se imprimían por contacto suponemos que el tamaño de las placas era cercano a los $17 \times 22$ centímetros; utilizaba objetivo 9 normal (el objetivo que se considera normal es aquel que tiene un ángulo de visión similar al del ojo humano, es decir, entre 45 y 50 grados de apertura y 200 milímetros de distancia focal), y cámara de formato grande para el tamaño de negativo que suponemos utilizó; además, podemos observar que utilizó aberturas de diafragmas cerrados que proporcionan mucha profundidad de campo ya que encontramos detalles nítidos en los diferentes planos de las imágenes.

Las fotografías muestran un ligero oscurecimiento en las esquinas, fenómeno

\footnotetext{
${ }^{9}$ Las funciones de la lente óptica como elemento simple montado al cuerpo de cámara fotográfica, es tomar un conjunto de rayos de luz que emanan de un objeto y redireccionar estos haces para que todos los rayos se vuelven a encontrar exactamente en el punto correcto para crear la imagen que se forma sobre el campo o soporte fotosensible. Se le conoce como objetivo a la serie de elementos (lentes) ópticos que acoplados conjuntamente en un barril (para la época de metal) corrigen las aberraciones ópticas que surgen en la cámara fotográfica. Es importante señalar que algunos investigadores insisten en utilizar el término lente, sin embargo, es impreciso ya que desde 1829 Charles Chevalier produjo un objetivo acromático de dos elementos (cristal de corona y cristal de roca) para reducir la aberración cromática en los experimentos de Daguerre (Kingslake, 1989).
} 
conocido como viñeteado (en algunas imágenes es más evidente que en otras), seguramente debido a que los objetivos de la época no eran tan perfectos como los actuales, por lo que las fotografías tenían pequeñas aberraciones ópticas, o porque se tenía una adaptación mal hecha del objetivo disponible al formato de la cámara, enfocando perfectamente en el centro y no así en las orillas; además, en ocasiones, para corregir la perspectiva de los edificios se desplazaba el plano de la película quedando fuera del eje del objetivo o cuando se giraba el plano del objetivo buscando enfocar un plano inclinado. Por esos detalles se producían esos oscurecimientos en una o dos de las esquinas de la imagen.

Los positivos fueron realizados con la técnica a la albúmina, las impresiones son del tamaño del negativo ya que se realizaban por contacto ${ }^{10}$ con papel emulsionado. Las fotografías se encuentran con las esquinas recortadas en diagonal, probablemente para ocultar las imperfecciones técnicas (ya que debemos tener en cuenta que las esquinas de las fotografías de negativos al colodión comúnmente estaban manchados por ser de esta parte donde lo sujetaba el fotógrafo al momento de emulsionar), también era común que estuvieran oscurecidas por defectos ópticos y porque muchos de los chasises tenían unas cintas que sujetaban la placa de las esquinas, por lo que algunos fotógrafos utili-

${ }^{10}$ En la época que refiere la presente investigación no existían las ampliadoras fotográficas como las actuales y fueron muy pocos los fotógrafos que hicieron impresiones en tamaños diferentes a los del negativo, muchas veces producto de reprografías del positivo con cámara de negativo de un tamaño diferente al de la toma original. zaban un papel emulsionado más pequeño que el negativo al momento de la impresión o lo recortaban posterior a esta, otros recortaban únicamente las esquinas como suponemos es el caso de las fotografías a las que nos referimos.

Las fotografías están pegadas sobre cartón ocre claro y en algunos casos en blanco, el cartón lleva en litografía negra el título del álbum, el tipo de edición, y en la parte inferior tiene el nombre de la fotógrafa como editora y propietaria, además la imagen se encuentra reencuadrada con marco de doble línea con esquinas elegantemente decoradas con diseños fitomorfos en ángulo y en ciertos casos con diseños de mixtilíneas. Por sus materiales, diseños de recuadros y tipográficos, se perciben al menos tres tipos de cartones diferentes, incluso las dimensiones entre los gráficos son un poco diferentes.

Las entrehojas que acompañan a las fotografías del Nacional Monte de Piedad, de la hacienda de La Castañeda, del mercado de Santa Catarina, de iglesias (del Carmen, Balvanera y la del Pocito de Guadalupe), son de dimensiones poco mayores a los cartones de las fotografías, están impresas con tipos móviles en hojas delgadas y tinta negra, con diseño tipográfico de caja de texto a dos columnas con título o nombre del lugar centrado en la parte superior. Los textos describen el lugar que vemos en la toma fotográfica y algunos están firmados por La Editora, como es el caso de la iglesia o capilla del Pocito de Guadalupe y del mercado de Santa Catarina; solamente el texto de La Castañeda está firmado por Enrique de Viralva y las otras tres no tienen firma. Es importante destacar que hay pequeñas diferencias entre los grosores y texturas 
de los papeles, así como de las fuentes tipográficas utilizadas.

Analizando el diseño de los cartones se podría considerar que fueron manufacturados en imprentas diferentes, y también dan la posibilidad de agruparlas de la siguiente manera: el diseño fitomorfo de forma cuadrada lo tienen las fotos de la iglesia del Carmen y la del mercado de Santa Catarina y en las entrehojas de ambas anotó que fueron fotografiados en septiembre de 1882; el diseño mixtilínea lo encontramos en las imágenes de la iglesia de Balvanera fotografiada en noviembre de 1882 y en la de la hacienda de La Castañeda realizada en enero de 1883; el diseño fitomorfo triangular lo ostentan las fotografías del Nacional Monte de Piedad y de la iglesia del Pocito de Guadalupe que no están fechadas las entrehojas, así como las fotografías de la Casa de los Mascarones, el convento de la Enseñanza, y las iglesias de San Fernando y Santiago Tlatelolco, que desafortunadamente no cuentan con entrehoja o algún tipo de anotación que nos permitan fecharlas.

También llamó nuestra atención la manera tan inusual en que María Guadalupe Suárez escogió los puntos de vista para las composiciones fotográficas, diferentes en la mayoría de las tomas realizadas por sus contemporáneos, como es el caso de la fotografía del mercado de Santa Catarina, dando cuenta de una ciudad a punto del cambio, ya que otras imágenes realizadas dos o tres años después indican que los espacios se transformaron sustancialmente. Por lo anterior, estas fotografías son imágenes de gran valor historiográfico debido a que muchos de estos edificios han sufrido importantes modificaciones y algunos incluso han desaparecido.
Ahora bien, recordemos que durante la gestión de Manuel González como presidente de México en el periodo comprendido entre 1880-1884, se dio un gran impulso a la modernización y urbanización de México, destacando el rubro de las obras materiales, principalmente en lo que concierne a la ampliación de redes ferroviarias, entre ellas la de ferrocarriles urbanos y suburbanos.

Un ejemplo de estas labores lo tenemos en la fotografía que realizó María Guadalupe Suárez de la hacienda de La Castañeda (véase imagen 1). Dicho registro captó la finca en el momento en que se extendieron las vías del ferrocarril hasta llegar a sus puertas. En esa época, de la vía que iba de la ciudad de México hasta San Ángel se desprendió un ramal, a medio kilómetro de la estación de Mixcoac, con el fin de llegar a la hacienda de La Castañeda. Con esa mejora se incrementaron considerablemente el número de visitantes que disfrutaban de alegres fines de semana. ${ }^{11}$ Durante el periodo que nos ocupa, esta hacienda ya era famosa por su producción de frutas y de pulque, y porque su dueño, el señor Manuel Carrera, incrementó estos atractivos al convertir parte de la finca en el Centro Recreativo Campestre, "en cuyos jardines y salones de baile los capitalinos de fines del siglo XIX encontraron esparcimiento por 25 centavos el boleto" (Chávez, 2005, p. 49). La publicidad de la época, que se hacía acompañar con una fotografía, decía sobre el Centro Recreativo:

La Castañeda, gran tívoli y casa especial para paseo y temperamento. Ferro-carril directo

${ }^{11}$ Enrique de Viralva. La hacienda de La Castañeda (en Suárez, 1882-1883). 


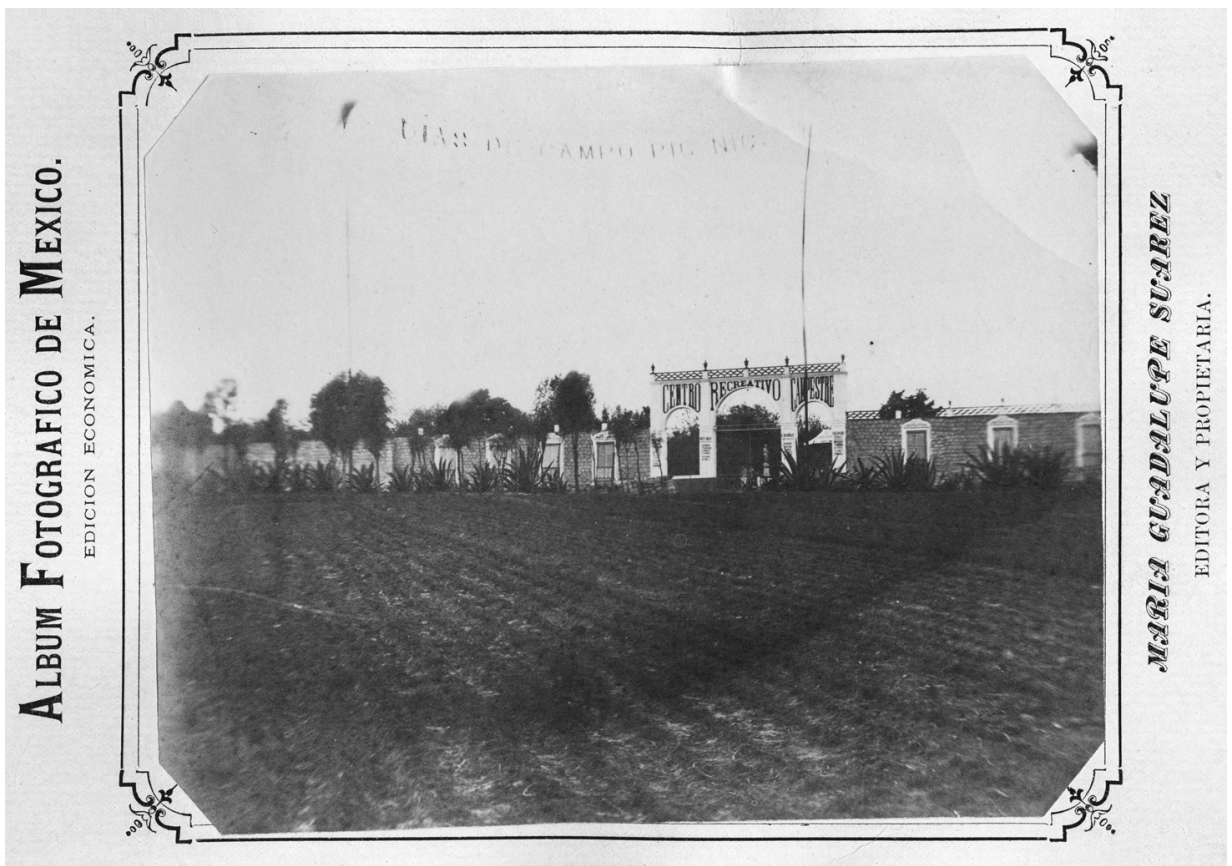

Imagen 1. María Guadalupe Suárez. Hacienda de La Castañeda. Fotografía a la albúmina. Distrito Federal, México, enero 1883. () (455151) CONACULTA.INAH.SinAFO.FN.México.

y teléfono. Gran huerta: juegos diversos y salones amueblados para días de campo y bailes. Cuartos y viviendas vacías y con muebles. Restaurant y Cantina. Precios muy baratos.

Lotes de venta, a pagar en 2 años con $\$ 2$ y $\$ 3$ mensuales. Véanse los avisos. México S. Ildefonso 7. M. Carrera Lardizabal. On Parle francais. English spoken. Man Spricht Deutsch. ${ }^{12}$

12 Autor no identificado. Fotografía a la albúmina. Fototeca Nacional/ SINAFO/ CONACULTA/ INAH, 454531 .
Esta fotografía de la hacienda de La Castañeda fue tomada por María Guadalupe Suárez en enero de 1883, debido a la petición que le hizo Enrique Viralva, según datos de la entrehoja de la misma fotografía. La fotógrafa realizó la toma extremadamente abierta desde un punto de vista frontal; se puede observar el detalle de la construcción con su imponente fachada de tres arcos sobre los que se ostenta el nombre de Centro Recreativo Campestre, y a los lados de estos se observan unos postes altos que sostienen un banderín que dice "Día de campo Pic nic". Para ello alejó su cámara considerable- 
mente para mostrar todo el largo del edificio, lo que provocó que el espacio ocupado por este fuera de una tercera parte del tamaño de la imagen, por lo que el campo que se encuentra frente a la portada del edificio toma mucha importancia, tanto por la proporción que ocupa como por el tono obscuro. Una veintena de años después de tomada esta foto, la finca fue adquirida por el gobierno de Porfirio Díaz para construir el manicomio general, que sería inaugurado el 1 de septiembre de $1910 .^{13}$

En la fotografía de la iglesia de Santiago Tlatelolco (véase imagen 2), construida en $1527,{ }^{14}$ es curioso ver que María Guadalupe Suárez no eligió para la toma fotográfica la fachada de cantera que se encuentra orientada al poniente, sino que eligió la parte posterior de la iglesia con sus muros lisos y de gran espesor. Posiblemente registra la iglesia desde este ángulo, dando cuenta del lugar en el que en 1882 se decide construir una nueva aduana. En ese año, el gobierno federal y el Ayuntamiento explicaron que la situación de la antigua aduana en la plaza de Santo Domingo era demasiado céntrica y ocasionaba aglomeración de vehículos. Para evitar esa situación, el ayuntamiento donaría unos terrenos ${ }^{15}$ por el rumbo de Santiago Tlatelolco a fin de que las auto-

${ }^{13}$ En 1881 el secretario de Gobernación para determinar la conveniencia de establecer un manicomio para establecer los hospitales de hombres y de mujeres dementes de la capital y establecer en dónde debía situarse. El proyecto finalmente se ejecutó y dio lugar al manicomio general en los terrenos de la ex hacienda de La Castañeda (Sacristán, 2013, p. 359).

${ }^{14}$ Iglesia de Santiago Tlatelolco. Recuperado de: http://www.tlatelolco.inah.gob.mx/iglesia.html

${ }^{15}$ Fondo Ayuntamiento. Gobierno del Distrito Federal. Sección Terrenos, 4045 1245, 1882. Archivo ridades trasladaran la aduana a aquella zona. Otros argumentos más fueron que existía un proyecto de alineamiento de las calles de la ciudad y porque Santiago era un lugar más cercano a las estaciones de ferrocarriles (Valle, 1884, p. 36). Volviendo a la fotografía de la iglesia, también es factible que la fotógrafa haya realizado tomas desde otros ángulos del edificio, pero la que llegó hasta nosotros es esta.

Podemos observar que realizó la toma fotográfica muy abierta en formato horizontal, colocándose ligeramente desde el ángulo derecho, con punto de vista a nivel del ojo, por lo que tuvo que alejarse para que el edificio quedara completo en la placa fotográfica. Se observan dos personas, una a cada lado de la puerta izquierda, una está fija y la otra se observa en movimiento barrido, lo que da cuenta de que la fotografía se tomó con una velocidad de obturación baja.

Como ya se indicó, entre los años 1880 y 1884 se llevó a cabo un proyecto de alineamiento de varias calles de la ciudad, como la de 5 de Mayo, y la mejoría en las calzadas de la Piedad, Tlalpan, Niño Perdido y Peralvillo (Enciclopedia, 1978, t. X, pp. 2260-2270). Uno de estos espacios fue registrado por María Guadalupe Suárez antes de que se concretara el proyecto.

En la imagen del Nacional Monte de Piedad (véase imagen 3) vemos el edificio de la institución que fue creada como casa de empeño y cuyas utilidades eran encauzadas para la beneficencia. María Guadalupe Suárez realizó esta fotografía poco antes de que se ampliaran los callejones de Mecateros y Arquillo para alinearlos a las calles de 5 de Mayo. La obra se

Histórico del Distrito Federal (citado en Aguayo y Vidali, 2013, vol. 1, p. 87). 


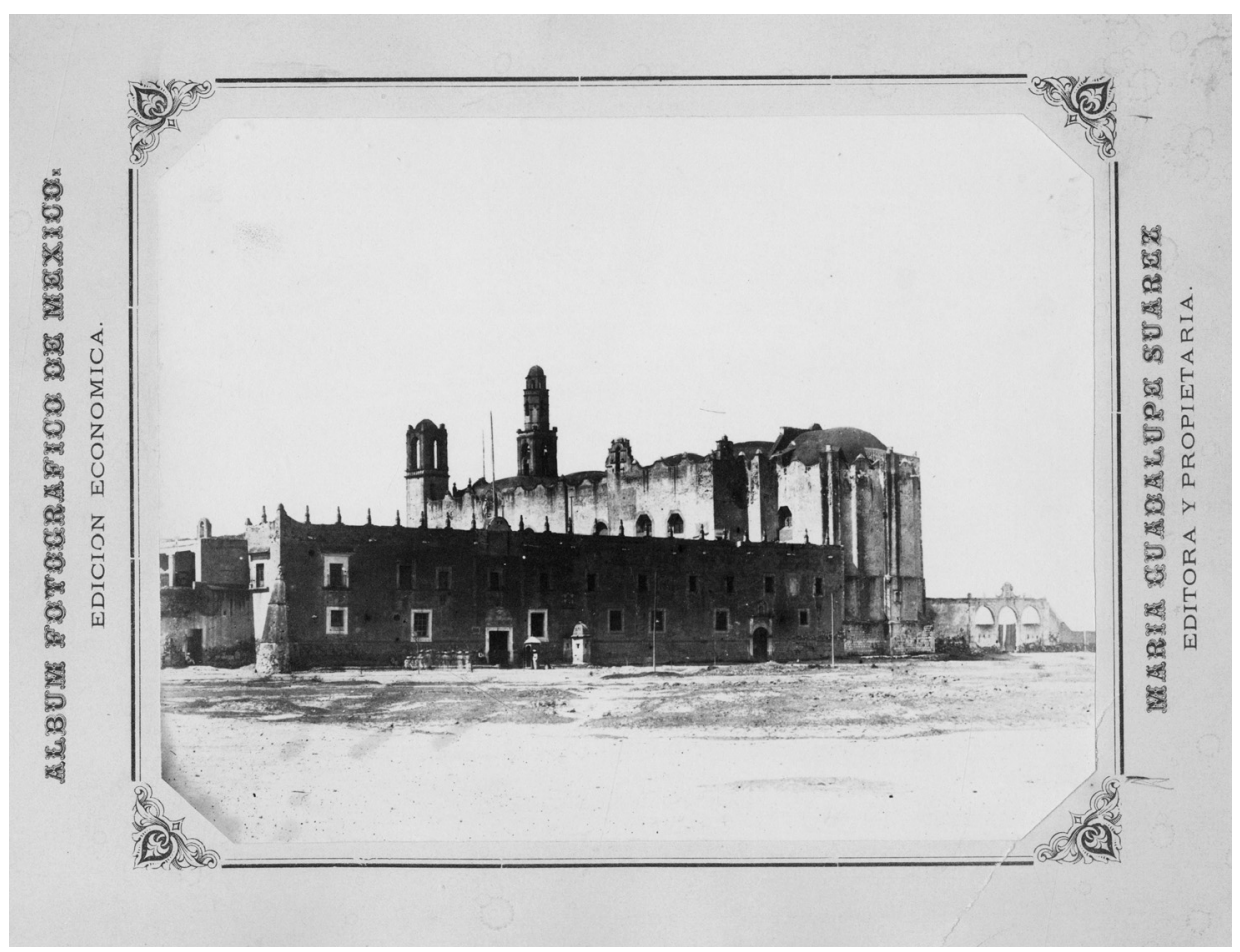

Imagen 2. María Guadalupe Suárez. Iglesia de Santiago Tlatelolco. Fotografía a la albúmina. Distrito Federal, México. (C) (455149) ConaCulTA.INAH.SinAFo.FN.México.

realizó en 1882, lo que mejoró sustancialmente el acceso al Nacional Monte de Piedad, además de que las fincas de su propiedad aledañas al edificio aumentaron de valor (Rincón, 1882, p. 6). En la imagen del edificio se observa que aún se encuentra el callejón y el edificio de la esquina contigua, que fue modificado para dar continuidad a la calle de 5 de Mayo, que comunicaría el Teatro Nacional con el Zócalo de la capital. En esa época el edificio aún contaba con tres plantas y sus muros eran claros con cantera en los marcos de ventanas y puertas; actualmente cuenta con cuatro plantas y los muros están recubiertos por tezontle, aunque sigue conservando la cantera original.

Otra cosa que llamó nuestra atención es que en dos de las puertas del edificio se observan personas elegantemente vestidas y con sombrero, lo que nos da un parámetro para ver lo altas que son las puertas del edificio. Para realizar esta fotografía, María Guadalupe Suárez se colocó a nivel de calle desde el lado norte-poniente del atrio de la catedral de México, realizó la toma abierta para registrar todo el edificio, se observan que las verticales están caídas 


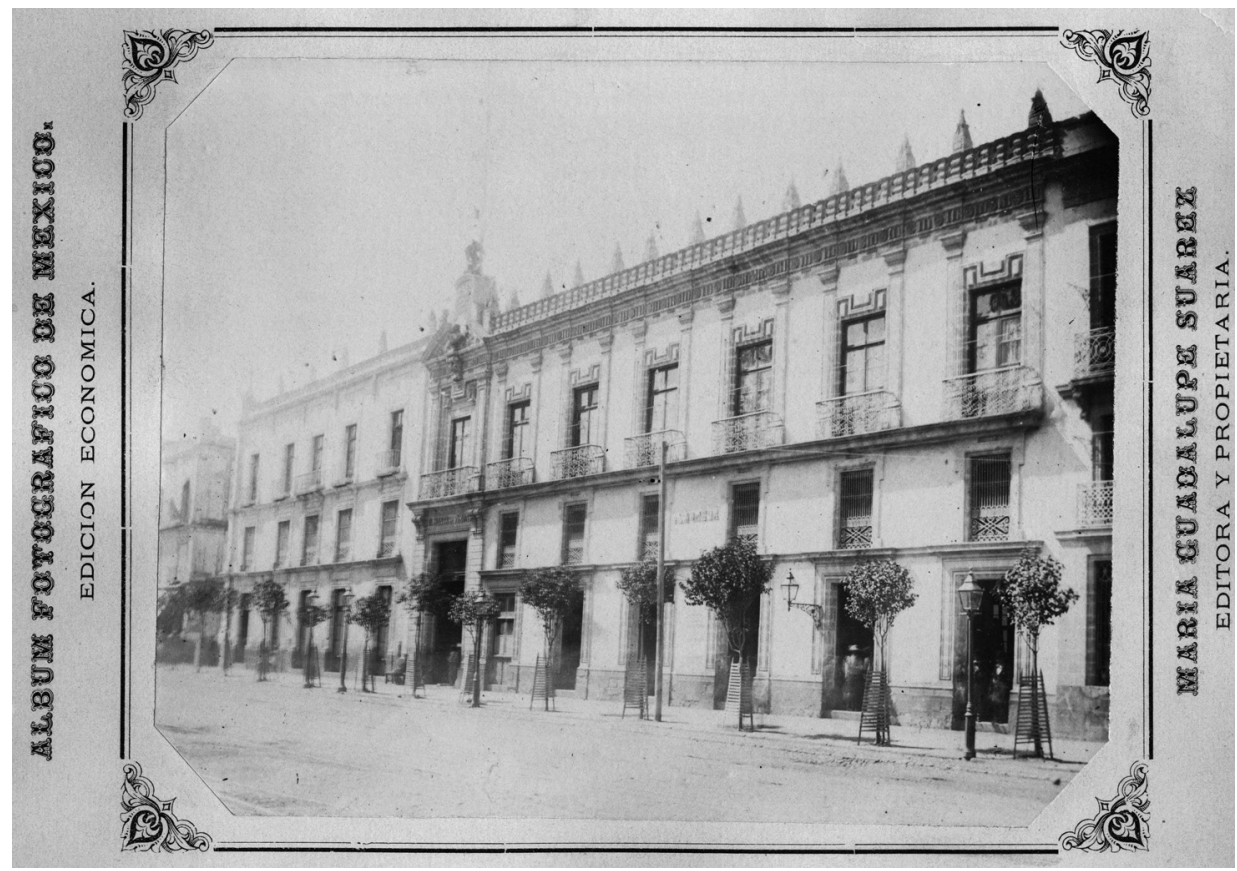

Imagen 3. María Guadalupe Suárez. Nacional Monte de Piedad. Fotografía a la albúmina. Distrito Federal, México. (C) (455148) Conaculta.InAH.SinAFo.FN.México.

seguramente porque el respaldo de la cámara de gran formato no está paralelo a la fachada del edificio. De esta toma hemos encontrado dos positivos en la Fototeca Nacional, uno de ellos se encuentra montado en cartón con entrehoja y texto firmado por La Editora (véase imagen 4), como se mencionó con anterioridad, y el otro se encuentra sin referencias; este último es de dimensiones un poco menores por todos sus lados, lo que es muy evidente porque no incluye la puerta del extremo derecho del edificio en la que se encuentran personas paradas; sin embargo, es de destacar que las esquinas también están cortadas en diagonal.
La construcción de la iglesia de San Fernando se comenzó en 1735 y fue concluida en 1755 , bajo la orden de los religiosos fernandinos que se deriva de los franciscanos. En 1860 la orden fue suprimida, dividiéndose el convento, huertas y potrero en lotes que se vendieron a particulares. En 1862, como parte de ese proceso de ensanchamiento de la ciudad, se abrió la calle de Guerrero, quedando del convento tan solo la iglesia (Rosell, 1961, pp. 239-244) en la esquina de lo que fue el antiguo camino a Tacuba, hoy Avenida Puente de Alvarado.

Para realizar la fotografía de la iglesia de San Fernando (véase imagen 5), María 


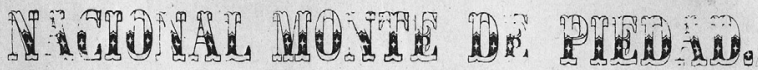

El Sr. conde de regla, D. Pedro Romero de Terreros, destinó 300,000 pesos para fundar este establecimiento con que aliviar á los necesitados, prestándoles las sumas que hubieren menester, librándoles así de caer en manos de frios y egoistas usureros. Fué aprobado el proyecto por real cédula de 2 de Junio de 1774; se hizo saber al público por bando de 11 de Febrero de 1775 , y se abrió el despacho el 25 del mismo mes, en la parte que se le destinó en San Pedro y San Pablo. Allí permaneció por algun tiempo; estuvo despues en la calle de San Juan de Letran, y hoy se encuentra en el número 8 del Empc. dradillo, cuya casa le pertenece.

No se cobraba cantidad alguna por el empaño; se dejaba en libertad á los individuos para que dieran la limosna que á bien tuvieran; como siempre, los agraciados abusaron del beneficio, y salidos del ahogo, no tenian empacho en mostrarse ingr itos, por lo que fué preciso señalar una cuota que se descontaba al tiempo de empeño.

\section{EN LA ACTUALIDAD.}

El 1. ${ }^{\circ}$ de Noviembre de 1878 , siendo Director el Sr. D. Mariano Riva Palacio se estableció la Almoneda para la calle, habiéndose introducido poco despues las mejoras de solicitar la venta de las partidas en cualquier tiempo ántes de su vencimiento.

En $1 .^{\circ}$ de Julio de 1880 se pusieron en circulacion jos billetes de este Establecimiento y se inauguraron las operaciones bancanas bajo la administracion del actual Directc,:, Sr. D. Trinidad García, quien tarnbien dispuso se trasladaran las oficinas á la parte bruja con el objeto de facilitar 1:v operaciones, habiendo tenido esto verifi. cativo en 6 de Enero de 1881 y siendo estas acertadas disposiciones, las que honran altamente, tanto al señor Director, comóa los miembros que componen la Juuta Gubernativa, por el muy buen resultado que han dado, redundando en provecho de íos fondos del Montepío.

\section{SUCURSALES}

Mandáronse establecer por el supremo decreto de 6 de Julio de 1866. Tienen por objeto socorrer á las gentes infelices bajo las equitativas condiciones del Monte de Piedad, á fin de librarlas de las exijencias punibles de los usureros y se establecieron en 1866. Por causas excepcronales se instalaron otras cuatro Sicursales en 1877 en las que se cobraba un $12 \%$ siendo así que en las anteriores tan solo se cobrabà un $8 \%$, continuando así hasta el dia 1 del presente en que por disposicion de la Júnta Gubernativa se cobrará en todas $4 \%$ en los primeros cuatro meses y ocho del quinto al octavo mes.

Tambien existe otra Sucursal establecida en la ciudad de Puebla, la que se inauguró el $1 .^{\circ}$ de Agosto de 1881, en donde se verifican las mismas operaciones que las que se hacen en la Casa Matriz.

Imagen 4. María Guadalupe Suárez. Nacional Monte de Piedad. Entrehoja de Fotografía. Distrito Federal, México. (C) (455148-A) ConaCulTA.INAH.SinAFO.FN.México.

Guadalupe Suárez colocó su cámara casi en contraesquina, captando el edificio con su amplia nave en perspectiva, lo que nos permite apreciar el templo austero y sencillo, con su fachada y portada de cantera con óculo central y una torre, así como el ancho muro lateral izquierdo; sin embargo, observamos la imagen inclinada por el desnivel en la cámara. En la imagen el templo luce muros claros, que actualmente se encuentran recubiertos de tezontle. El terreno vacío que se encuentra junto al muro hace más imponente la imagen del templo; cabe destacar que en ese lugar ahora se localiza un hermoso edificio del porfiriato con fachada a la dicha avenida Guerrero.

La avenida de Puente de Alvarado más hacia el poniente toma el nombre de Rivera de San Cosme, en la que se encuentra la llamada Casa de los Mascarones (véase imagen 6). Dicha construcción sirvió de casa de campo de don José Diego Hurtado de Mendoza, conde del Valle de Orizaba. Esa finca se inició en 1562, pero permaneció inconclusa y abandonada hasta 1822, cuando se subastó; los diferentes 


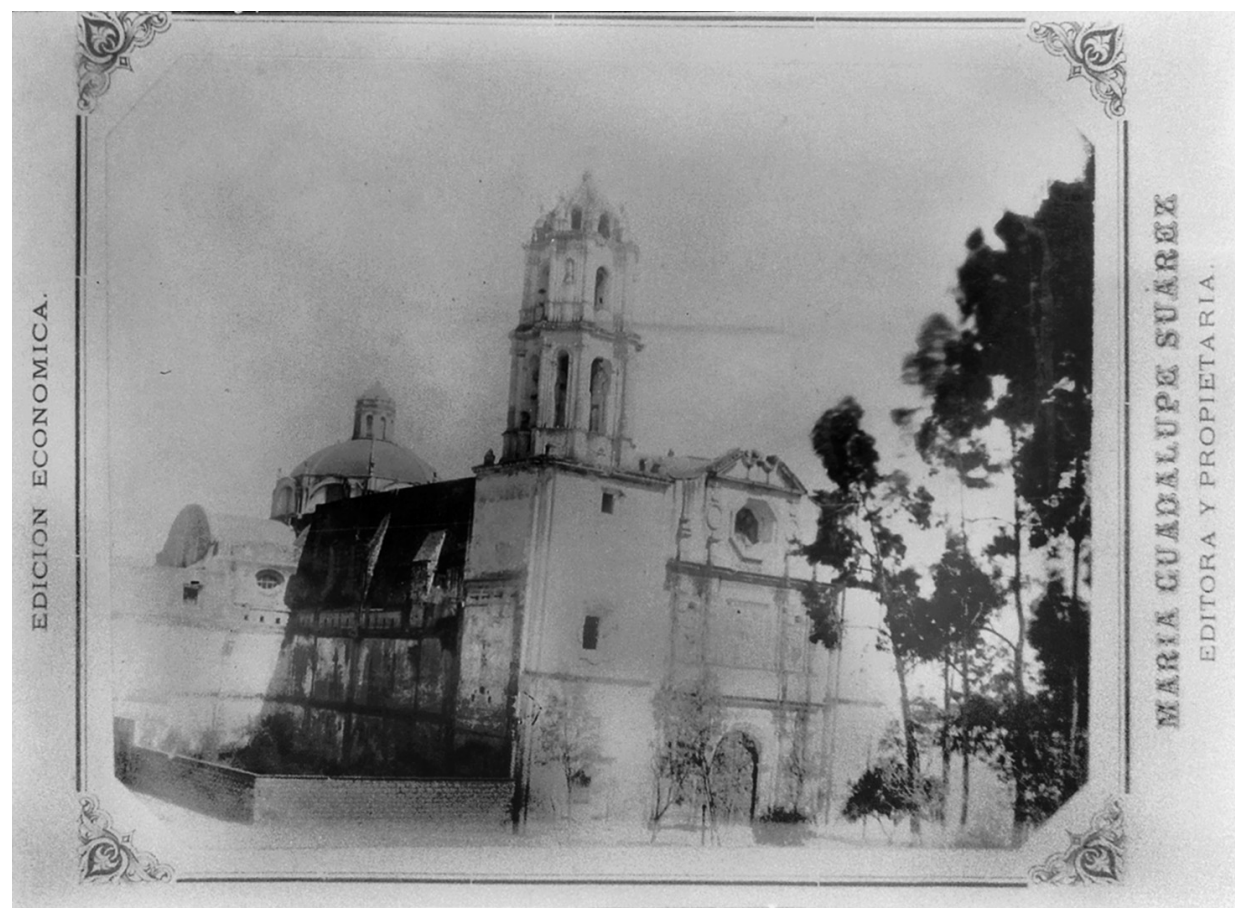

Imagen 5. María Guadalupe Suárez. Iglesia de San Fernando. Reprografía del original en placa negativa de nitrato de plata en formato $5 \times 7$ pulgadas, positivada digitalmente. Distrito Federal, México. Fototeca Constantino Reyes-Valerio. (CXXIII-81) ConACULTA-INAH-Méx. Reproducción autorizada por el Instituto Nacional de Antropología e Historia.

propietarios que tuvo concluyeron la construcción. También sirvió como albergue a diferentes colegios, hasta que en 1929 fue incorporada al patrimonio de la Universidad Nacional Autónoma de México (Rojas, 1985, pp. 7-31).

Para realizar la fotografía de ese edificio, María Guadalupe Suárez colocó la cámara a la izquierda del predio, en perspectiva para realizar la toma abierta; sin embargo, las verticales le quedaron ligeramente caídas en los extremos por la nivelación del respaldo de la cámara. En la imagen se observan los muros de mampostería almohadillada, así como el frontis, los seis pilares con su pedestal ornamentado en el que se apoya un atlante sosteniendo el capitel, así como los marcos de los vanos labrados en cantera. La imagen está ligeramente desvanecida porque se observa que se pierden sutilmente los detalles en las luces, es posible que esta pérdida de contraste sea efecto del deterioro de la pieza.

Otra de las imágenes de nuestra autora es la iglesia o capilla del Pocito de Gua- 


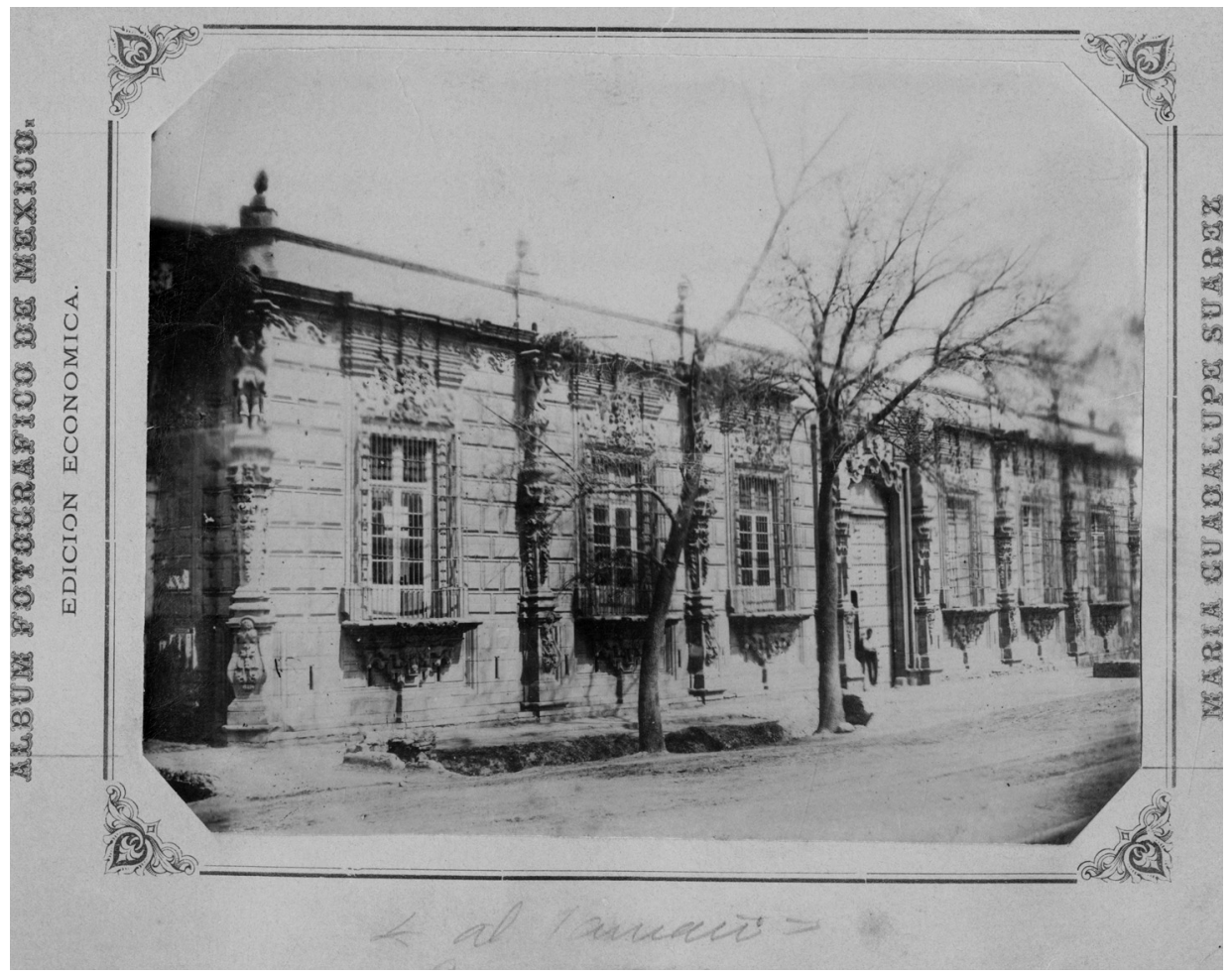

Imagen 6. María Guadalupe Suárez. Casa de los Mascarones. Fotografía a la albúmina. Distrito Federal, México. (c) (428691) Conaculta.INAH.Sinafo.FN.México.

dalupe (véase imagen 7) que se encuentra en el cerro del Tepeyac. Esa iglesia comenzó a construirse en 1777 y tardó en terminarse 14 años. ${ }^{16}$ Para realizar la fotografía del Pocito, María Guadalupe Suárez colocó su cámara en formato vertical, encuadrando el edificio de estilo barroco con base circular o cántrica, desde un punto de vista alto, al parecer en la subida

\footnotetext{
${ }^{16}$ María Guadalupe Suárez. Iglesia o capilla del Pocito de Guadalupe (en Suárez, 1882-1883).
}

al cerro que se encuentra enfrente al templo. La luz es suave y en dirección frontal, expuso y reveló correctamente la placa, ya que así lo demuestra el detalle que se observa tanto en las luces como en las sombras.

Comparándola con otras fotografías de la época realizadas por Alfred Briquet y por la firma Gove and North, resulta que existieron dos tipos de encuadres. Casi todas las de otros autores son tomas extremadamente abiertas, en formato horizontal en donde se observan las construccio- 


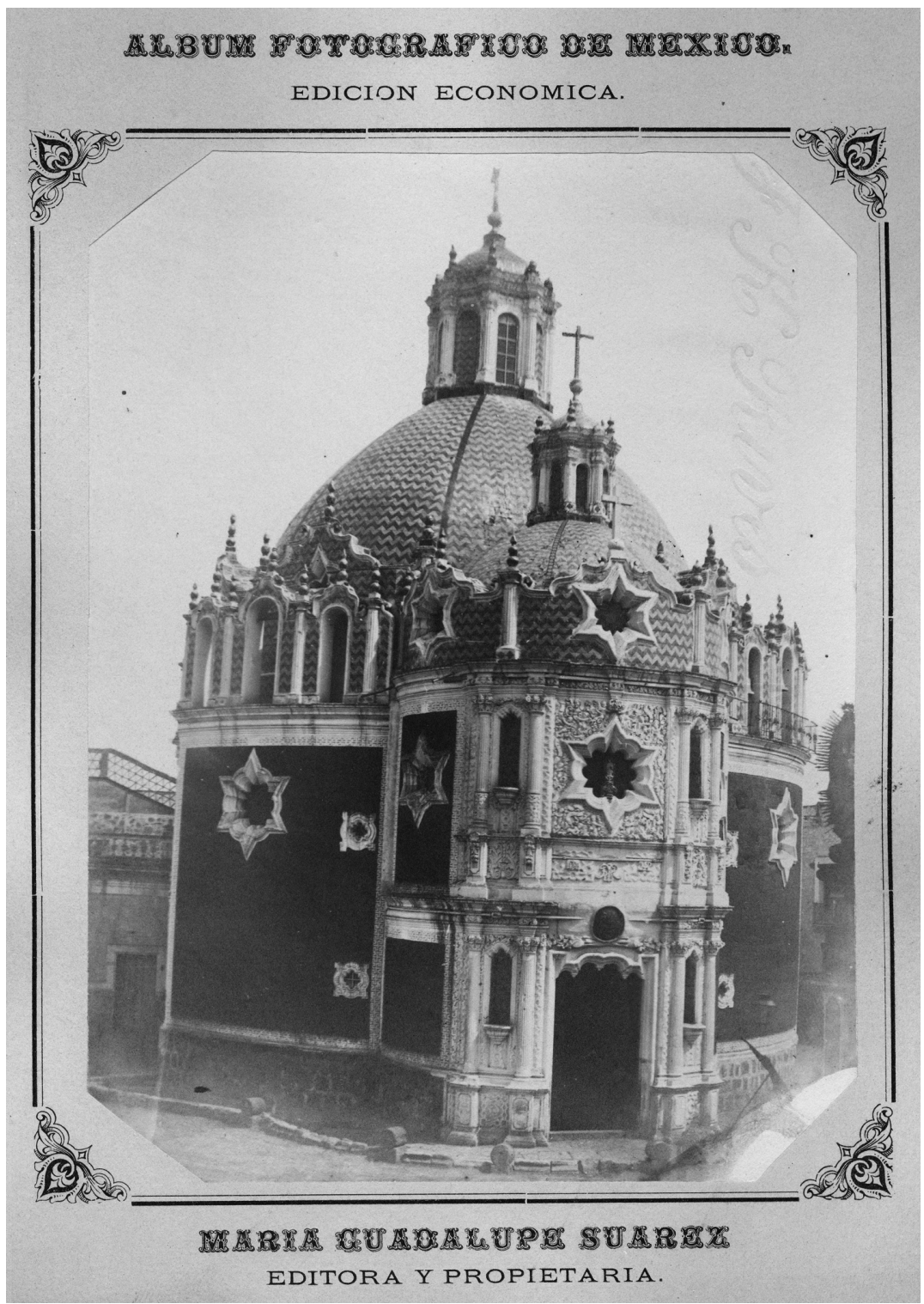

Imagen 7. María Guadalupe Suárez. Iglesia o capilla del Pocito de Guadalupe. Fotografía a la albúmina. Distrito Federal, México. (C) (455150) ConACUlTA.INAH. SINAFO.FN.México.

\section{(c) (1) $\$$}

Atribución-NoComercial 4.0 
nes circundantes y en todas ellas aparecen personas frente al edificio; mientras que en las pocas tomas abiertas en formato vertical, estas son muy similares a la de nuestra fotógrafa; sin embargo, se observa que en la imagen de nuestra reseñada la luz es más dura, marcando fuertemente las sombras, además de que el ángulo de toma es ligeramente más a la derecha, por lo que en la toma de María Guadalupe Suárez la cruz de la cúpula se observa completamente de perfil. Esta pieza presenta un desdoblamiento de la emulsión del negativo al colodión, en el ángulo inferior derecho de la imagen, además de que la toma fotográfica se encuentra ligeramente desnivelada.

En los años que reseñamos, el presidente Manuel González promovió la introducción del agua potable desde Santa Fe y el distrito de los Leones, como una medida para enfrentar la insalubridad y las enfermedades endémicas o epidémicas. También se tomaron medidas higiénicas y de abasto de alimentos con la edificación de mercados, como el de Santa Catarina (véase imagen 8), que se construyó en 1850 , en la calle que en ese entonces tenía el nombre de aquella santa, ${ }^{17}$ en el predio que actualmente se llaman de República de Brasil y Honduras, en el Centro Histórico. El mercado se llamó de Santa Catarina debido a que desde 1536 existió una ermita dedicada a Santa Catarina Mártir de Alejandría; frente a dicha ermita había una plazuela que servía de desahogo a "la lagunilla" que era una penetración del antiguo lago. Con el tiempo, mientras la ermita se ele-

\footnotetext{
${ }^{17}$ María Guadalupe Suárez. Mercado de Santa Catarina (en Suárez, 1882-1883).
}

vaba al rango de parroquia, en la plaza se instaló un mercado en el que se congregaban gran cantidad de indígenas. ${ }^{18}$

Ese mercado llegó a considerarse el tercero en importancia de la ciudad, después de El Parián y el de Tlatelolco. En 1881, por considerarse uno de lo más productivos y porque se encontraba en estado casi ruinoso, se realizó una reconstrucción del mercado (Lascuráin, 1881, p. 41). Es de destacar la preocupación en la época por la higiene y distribución de los alimentos para evitar la proliferación de epidemias, lo que llevó a la reestructura y edificación de importantes mercados, además del antes mencionado, el de San Juan y la Merced.

La fotografía que realizó María Guadalupe Suárez en septiembre de 1882 muestra el mercado de Santa Catarina recién reconstruido. El edificio que vemos en la imagen es muy singular: los muros de ladrillos eran a manera de columnas rectangulares separadas, con una entrada al centro de cada uno de sus cuatro lados, tenía un techo de fierro ${ }^{19}$ en cuatro niveles separados que permitían que circulara el aire y con inclinación para que el agua de lluvia escurriera. Además se sabe que en el interior tenía una fuente o toma de agua, muestra de la preocupación que por la higiene y salud tuvieron los gobernantes del Distrito Federal para acabar con epidemias como la del cólera.

Se observa que la autora realizó la toma fotográfica desde el edificio que se encuentra en la esquina de las calles de República

\footnotetext{
${ }^{18}$ Plaza de Santa Catarina Mártir. Recuperado de: http://ciudadanosenred.com.mx/plaza-de-santacatarina-martir/

${ }^{19}$ María Guadalupe Suárez. Mercado de Santa Catarina (en Suárez, 1882-1883).
} 


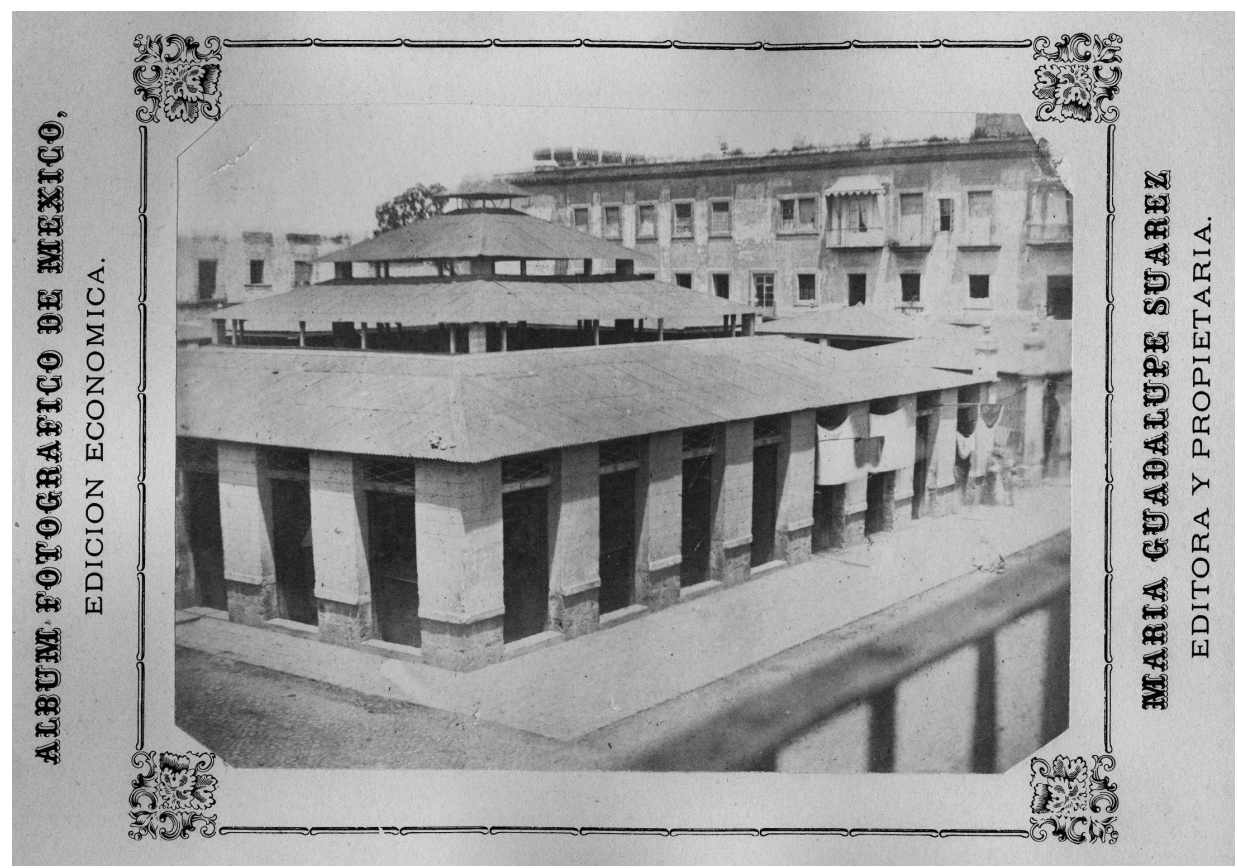

Imagen 8. María Guadalupe Suárez. Mercado de Santa Catarina. Fotografía a la albúmina. Distrito Federal, México, septiembre de 1882. (c) (455153) ConACULTA.INAH.SinAFo.FN. México.

de Honduras y República de Brasil, en contraesquina del mercado, con un punto de vista alto, posiblemente desde el balcón o azotea del edificio, ya que se advierte el barandal que se percibe en el primer plano de la imagen, mismo que no sale en foco porque está muy cerca del objetivo de la cámara.

Podemos observar una perspectiva parcialmente corregida que consiguió subiendo el respaldo de la cámara para que salga en la imagen la parte baja del mercado e incluso la calle. Para la época debió ser muy inusual el punto de vista que escogió la fotógrafa, captando el edificio desde la esquina y acentuando el uso de diagonales que imprime dinamismo a la imagen.

A unas cuantas calles del mercado de Santa Catarina se encontraba la iglesia Nuestra Señora del Carmen (véase imagen 9), en la plaza Del Estudiante número 8, antes plaza Del Carmen. Esta iglesia fue construida como iglesia del Tercer Orden de los Carmelitas Descalzos en 1742; en 1862 fueron derruidos el convento y la nueva iglesia que se estaba construyendo bajo el proyecto de Francisco Eduardo Tres Guerras, quedando únicamente el primitivo templo de planta basilical y bóveda de cañón que se conserva 


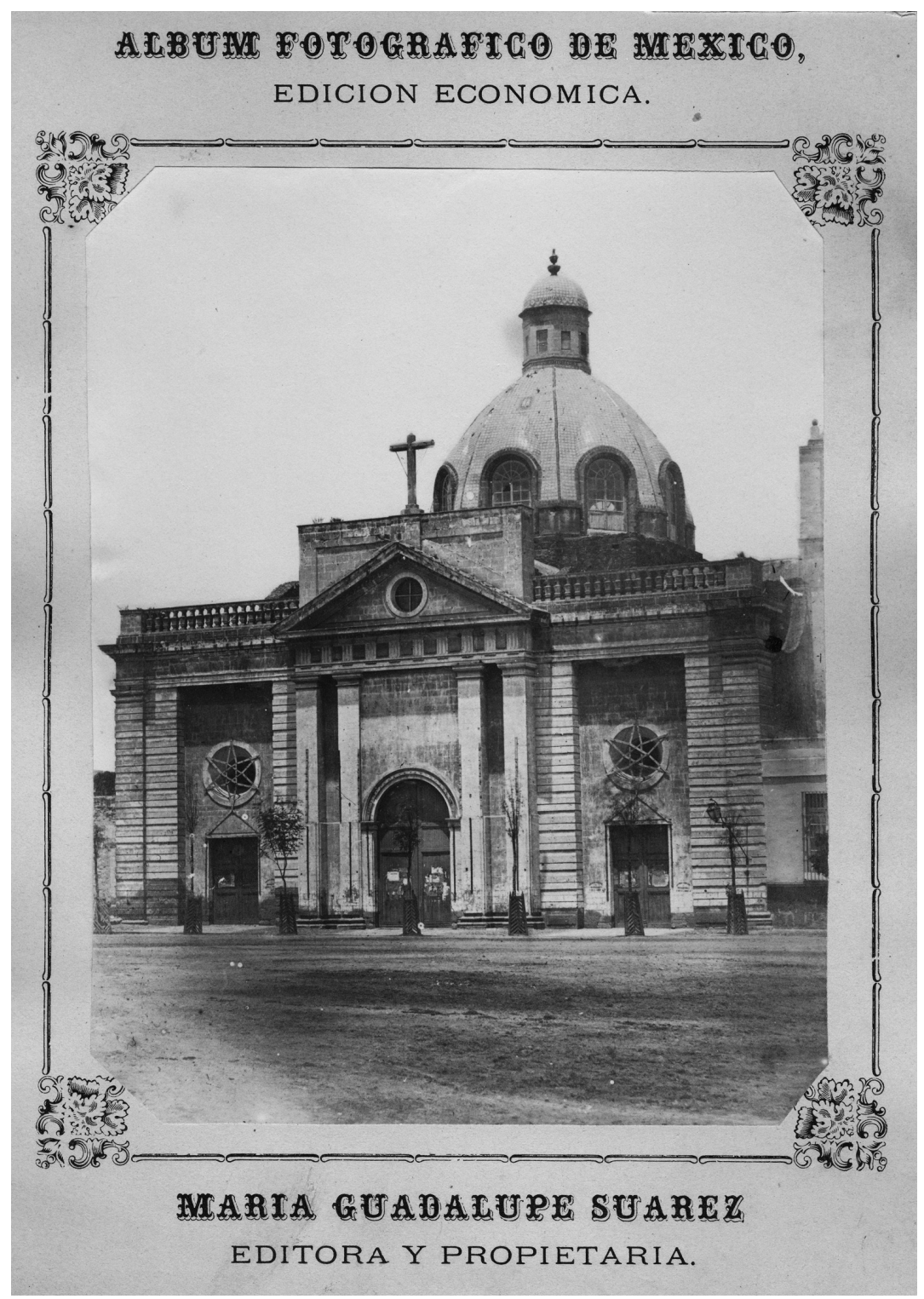

Imagen 9. María Guadalupe Suárez. Iglesia del Carmen. Fotografía a la albúmina. Distrito Federal, México, septiembre de 1882. (C) (455154) ConACUlTA.INAH. SINAFO.FN.México. 
hasta nuestros días. La fachada fue reformada entre los años de 1900 y 1903 (Rosell, 1961, pp. 231-233), lo que implicó que la iglesia perdiera sus columnas, frontón y cruz que coronaba el edificio, mismos que fueron sustituidos por una fachada más alta con óculo, reloj y la imagen de la virgen Del Carmen.

En septiembre de 1882, María Guadalupe Suárez colocó su cámara casi frontal a la portada de la iglesia para realizar su fotografía; podemos ver que al acomodarse ligeramente a la derecha consiguió un ángulo más interesante. Realizó a distancia una toma abierta en formato vertical con buen aprovechamiento del tamaño de la imagen y excelente exposición que muestran el detalle de la portada con su frontispicio, así como de la cúpula y linternilla revestidas de azulejos. También llama la atención el atrio despejado y sin gente ya que actualmente la iglesia se encuentra al filo de una calle estrecha y rodeada de comercio ambulante.

Otra medida de urbanización que se instaló en las calles de la ciudad, fue el sistema de alumbrado público con lámparas de gas, que años más tarde sería sustituido por el eléctrico (Enciclopedia, 1978, t. x, pp. 2260-2270). En dos de las fotografías de María Guadalupe Suárez podemos apreciar el sistema de alumbrado que consiste en los faroles adosados a las paredes de los edificios: de las iglesias de la Enseñanza (véase imagen 10) y de Balvanera (véase imagen 11). El edificio de esta última se encuentra en la calle de República de Uruguay número 36, fue fundada en 1573 por la cofradía de las monjas de la Concepción ${ }^{20}$ con el propó-

\footnotetext{
${ }^{20}$ María Guadalupe Suárez (atribuido). Iglesia de Balvanera (en Suárez, 1882-1883).
}

sito, según se dijo, de contrarrestar los efectos producidos por el progresivo aumento de la prostitución (Rosell, 1961, pp. 283-286).

María Guadalupe Suárez registra la fachada de la iglesia en noviembre de 1882, según lo indican la hoja de referencia que acompaña la fotografía. Utilizó una perspectiva desde el ángulo lateral derecho con un punto de vista alto; seguramente para realizar la toma fotográfica se colocó en la azotea del edificio que se encuentra en la intersección de las calles República de Uruguay y Correo Mayor, es decir, en contraesquina con el templo. Probablemente de haberse colocado de frente a la portada de la iglesia, el ancho de la calle no le hubiera permitido obtener más que un detalle de la misma. Por la perspectiva se observa que la fotografía se realizó con un objetivo o lente normal.

En la fotografía se observa el edificio de una nave que cuenta con dos plantas, dos portadas y una torre, en el exterior la protege una reja de acero con intercolumnios. En la actualidad, el templo conserva sus dos portadas gemelas y la torre decorada con azulejos, ornamentación derivada del arte árabe.

El convento de La Enseñanza se fundó en 1752 como una de las primeras escuelas para mujeres en el país. Para el año de 1863 las monjas fueron exclaustradas del convento y el edificio se transformó en flamante Palacio de Justicia (Rosell, 1961, pp. 297-202).

De las fotografías que hemos encontrado de María Guadalupe Suárez, la de este convento nos resulta muy particular ya que en las imágenes que hemos descrito anteriormente solamente dos presentan personas y, más bien, muestran calles vacías, situación que en parte se 


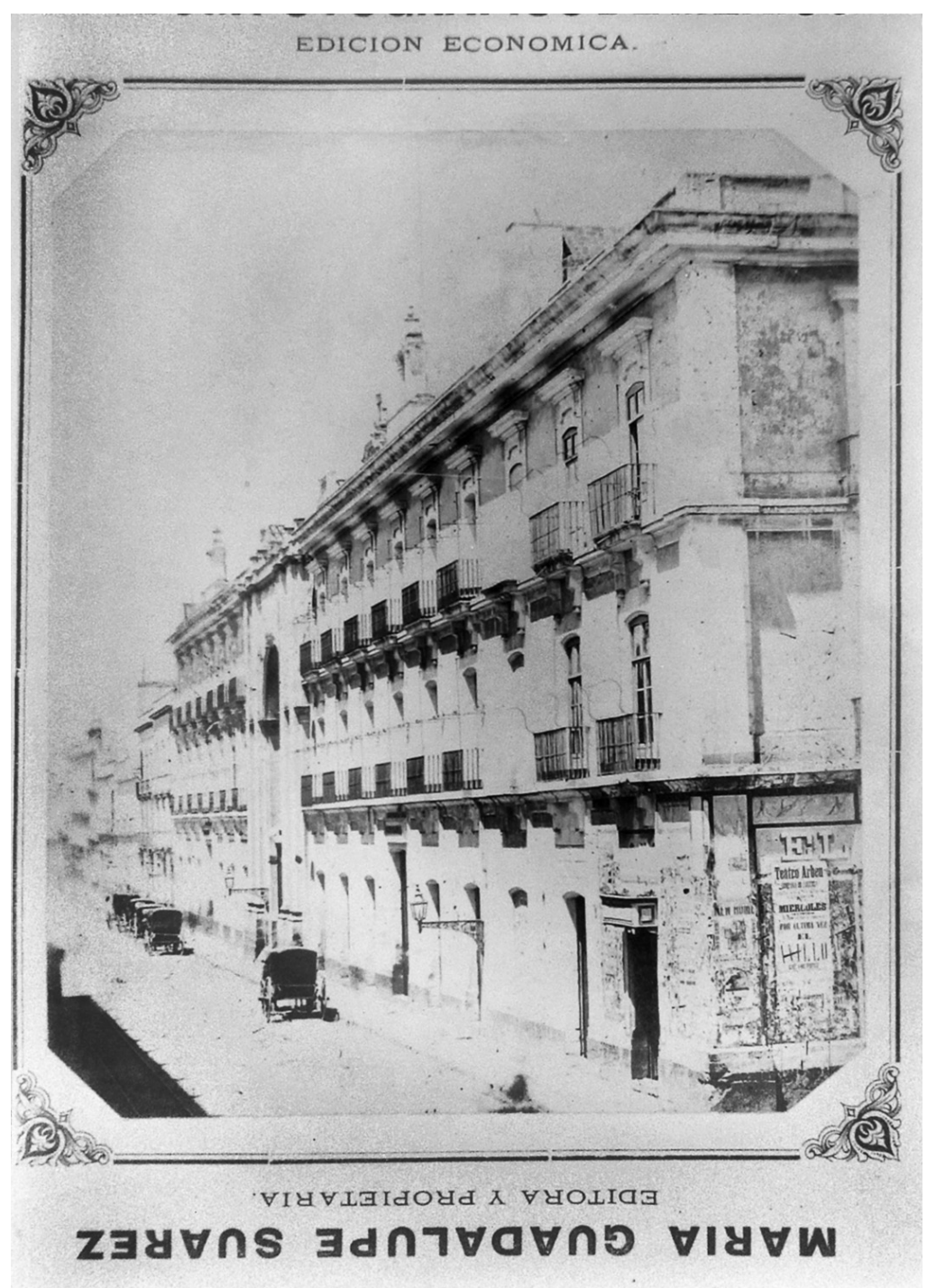

Imagen 10. María Guadalupe Suárez. Ex convento de La Enseñanza. Reprografía del original en placa negativa de nitrato de plata en formato $5 \times 7$ pulgadas, positivada digitalmente. Distrito Federal, México. Fototeca Constantino ReyesValerio. (CXXIII-80) CONACULTA-INAH-Méx. Reproducción autorizada por el Instituto Nacional de Antropología e Historia.

\section{(c) (1) $\$$}




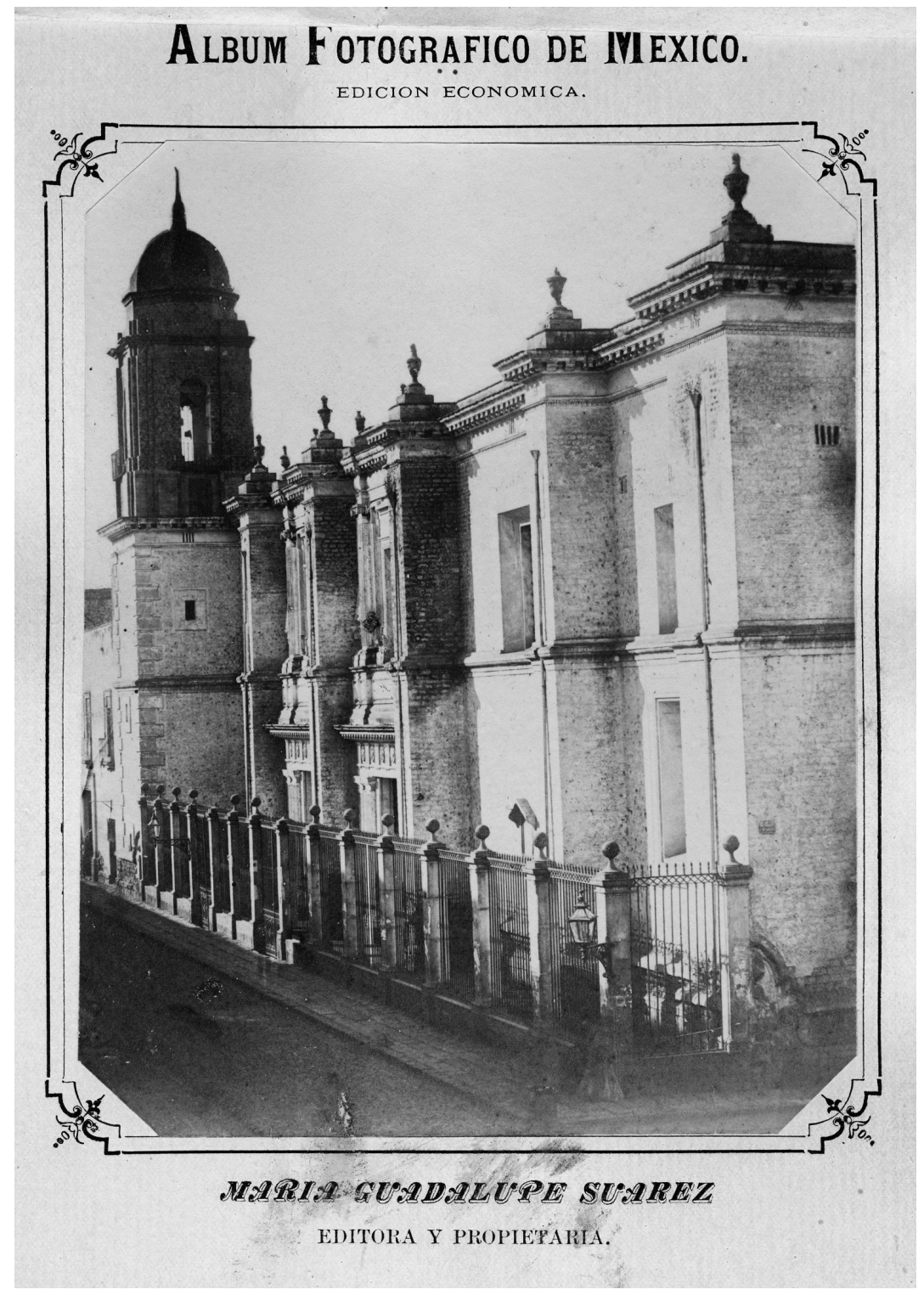

Imagen 11. María Guadalupe Suárez. Iglesia de Balvanera. Fotografía a la albúmina. Distrito Federal, México, noviembre de 1882. (C) (455152) CONACUlTA.INAH. SINAFO.FN.México.

\section{(1) (1) $\$$}


debe a los tiempos de exposición tan largos. Sin embargo, en la fotografía de la iglesia de La Enseñanza aparecen cinco carros estacionados sobre la antigua calle de Cordobanes, hoy Donceles, mientras que en el muro de la calle de Relox, ahora República de Argentina, se observa un cartel pegado anunciando funciones en el teatro Arbeu, lo que nos habla de la modernidad y el gusto por los espectáculos que se presentaban en aquella época.

También podemos ver en la fotografía el edificio de tres plantas desde una perspectiva surponiente, con entrada principal al centro y con un pequeño nicho en el que se encuentra la estatua de la virgen. Con el tiempo el convento tuvo importantes modificaciones, una de ellas es que el edificio fue dividido en dos partes: el lado derecho está ocupado por el Colegio Nacional y el lado izquierdo conserva lo que fue la entrada principal y su nicho restaurado; este edificio se ocupa para bodegas y comercios.

Es una pena que se conozcan únicamente diez fotografías realizadas por María Guadalupe Suárez ya que no nos permite darnos una buena idea de la calidad compositiva, manejo de cámara y de los procesos fotográficos que tiene. Podemos advertir que cuidaba la composición y conocía muy bien la luz, misma que aprovechaba realizando sus fotografías con detalle tanto en las luces como en las sombras, su manejo del proceso fotoquímico también era bueno aunque algunas fotografías muestran errores en el manejo de la emulsión de colodión que, como dijimos con anterioridad, se trataba de un proceso muy complicado. En cuanto al uso de la cámara observamos que algunas imágenes muestran pequeñas deficiencias en el manejo de la perspectiva, con verticales inclinadas y en algunos casos toda la imagen está caída hacia un lado, ligeros viñeteos, debido a perspectivas forzadas y corregidas al mover en la cámara el respaldo de la película y unas pequeñas entradas de luz en el negativo.

Compositivamente, las fotografías son diferentes a las realizadas por otros fotógrafos contemporáneos como Briquet, Jackson, Gove \& North o Becerril, quienes publicaron gran cantidad de grupos de vistas de México. Todos ellos utilizaban principalmente tomas extremadamente abiertas en formato horizontal que daban cuenta de los edificios y el entorno circundante. En menor medida realizaban tomas abiertas centrándose en el edificio; en estas últimas se encuentran mayores similitudes entre las fotografías de esos autores y las de María Guadalupe Suárez, sin embargo, sus temas y encuadres no son lo común de la época. Sin duda, buena parte de la trascendencia de esta fotógrafa radica en haber sido una de las primeras mujeres mexicanas en enfrentarse a los retos y problemas de una profesión tan complicada en ese momento de la historia de la fotografía.

Es pertinente señalar que el gran descubrimiento de las fotografías de María Guadalupe Suárez es tan sólo un adelanto de la investigación en curso que estamos realizando, ya que seguiremos indagando en torno a las fotografías y documentos de la ciudad de México en el periodo de 1880-1885, lo que sin duda contribuirá a tener otra historia de la fotografía en México. 


\section{LISTA DE REFERENCIAS}

-Aguayo, F. y Vidali, C. (2013). Un problema de la representación de la ciudad. En A. Salmerón y F. Aguayo, Instantáneas de la ciudad de México. Un álbum de 1880-1884. México: Instituto Mora.

-Chávez Aguirre, J. M. (2005). Río Mixcoac. Entre miradas de ojos verdes. México: FES Cuautitlán-UNAM.

-Chevrier, J.-F. (2007). La fotografía entre las bellas artes y los medios de comunicación. España: Gustavo Gili.

-Iglesia de Santiago Tlatelolco. Recuperado de: http://www.tlatelolco.inah.gob.mx/iglesia. html

-Kingslake, R. (1989). A History of the photographic lens. Reino Unido: Academic Press Limited.

-Krauss, R. (2002). Lo fotográfico. Por una teoría de los desplazamientos. España: Gustavo Gili.

-Landesio, E. (1867). La pintura general o de paisaje y de perspectiva, en la Academia de San Carlos. México: Imprenta de Lara.

-Lascuráin, P. de (1882). Discurso pronunciado por el regidor primero del Ayuntamiento constitucional de México en 1881. México: Imprenta Francisco Díaz de León.

-Mata, F. (1883). Anuario universal, año VI.

-Plaza de Santa Catarina Mártir. Recuperado de: http://ciudadanosenred.com.mx/plaza-desanta-catarina-martir/

-Rincón Gallardo, P. (1882). Discurso pronunciado por el regidor primero del Ayuntamiento constitucional de México en 1881. México: Imprenta Francisco Díaz de León.

-Rodríguez, J. A. (2012). Fotógrafas en México 1872-1960. España: Editorial Turner.
-Rojas, P. (1985). La Casa de los Mascarones. México: UNAM.

-Rosell, L. E. (1961). Iglesias y conventos coloniales de México [2a ${ }^{\mathrm{a}}$ ed.]. México: Editorial Patria.

-Sacristán, C. (2013). Los hospitales para dementes y el crecimiento de la ciudad. En A. Salmerón y F. Aguayo, Instantáneas de la ciudad de México. Un álbum de 1883-1884. México: Instituto Mora.

-Enciclopedia Historia de México (1978). México: Salvat Mexicana de Editores.

-Sougez, M.-L. (1999). Historia de la fotografía. España: Editorial Cátedra.

-Sougez, M.-L. y Pérez Gallardo, H. (2003). Diccionario de historia de la fotografía. España: Editorial Cátedra.

-Suárez, M. G. (ed. y prop.) (1882-1883). Álbum fotográfico de México. México.

-Valle, G. (1884). Discurso del segundo regidor del Distrito Federal, al instalarse el Ayuntamiento electo para 1883. México: Imprenta Francisco Díaz de León.

\section{OTRAS FUENTES}

Archivos y fototecas

AHDF Archivo Histórico del Distrito Federal.

FNM-INAH Fototeca Nacional de Monumentos-INAH.

FN-INAH Fototeca Nacional-INAH.

\section{Hemerografía}

La Libertad, 1881. 